\title{
Berpikir Pseudo Siswa pada Konsep Pecahan
}

\author{
Agus Alamsyah $^{1}$, Susiswo $^{2}$, Erry Hidayanto ${ }^{2}$ \\ ${ }^{1}$ Pendidikan Dasar-Universitas Negeri Malang \\ ${ }^{2}$ Pendidikan Matematika-Universitas Negeri Malang
}

\section{INFO ARTIKEL}

\section{Riwayat Artikel:}

Diterima: 16-05-2019

Disetujui: 19-08-2019

\section{kata kunci:}

think pseudo;

fraction concept;

berpikir pseudo;

konsep pecahan

\author{
Alamat Korespondensi: \\ Agus Alamsyah \\ Pendidikan Dasar \\ Universitas Negeri Malang \\ Jalan Semarang 5 Malang \\ E-mail: alamzyah.ajuz@gmail.com
}

\begin{abstract}
ABSTRAK
Abstract: Purpose of this research was to study students' pseudo thinking in concept of fractions. Data obtained using questions and interviews. Question used to find answers of students in understanding concept of fractions. Interviews used to find reasons for students answer. Findings show that students think pseudo conceptual, true-pseudo and false-pseudo. Pseudo conceptual thinking when students condition not understand shade when drawing fractions. Thinking true-pseudo when students in state not understand concept of drawing fractions begins with same size and broken down as much denominator fractions. Thinking false-pseudo when students state poor understanding problem and reflection for concept of drawing fractions.
\end{abstract}

\begin{abstract}
Abstrak: Tujuan penelitian ialah untuk mempelajari berpikir pseudo siswa dalam konsep pecahan. Data diperoleh dengan menggunakan instrumen soal dan wawancara. Soal digunakan untuk mengetahui jawaban siswa dalam memahami konsep pecahan. Wawancara digunakan untuk mengetahui alasan siswa dalam menjawab. Temuan menunjukkan bahwa siswa mengalami berpikir pseudo conceptual, true-pseudo dan false-pseudo. Berpikir pseudo conceptual saat siswa pada kondisi tidak memahami perlunya mengarsir saat menggambar pecahan. Berpikir true-pseudo saat siswa pada kondisi tidak memahami konsep menggambar pecahan berawal dari ukuran yang sama dan dipecah sebanyak penyebut pecahan. Berpikir false-pseudo saat siswa pada kondisi kurang memahami soal dan diperlukan refleksi konsep menggambar pecahan.
\end{abstract}

Pikir merupakan kata dasar dari berpikir. Berdasarkan Kamus Besar Bahasa Indonesia pikir berarti akal budi, ingatan, atau anganangan. Sehingga berpikir diartikan penggunakan akal budi dalam mempertimbangkan dan memutuskan sesuatu. Berpikir juga dapat diartikan sebagai berkembangnya ide dan konsep dalam diri seseorang. Sebagaimana menurut Subanji, (2016) berpikir merupakan aktivitas yang berada di otak sehingga berpikir tidak dapat dilihat. Namun, berpikir dapat dirasakan hasilnya. Berpikir penting bagi siswa sebagaimana menurut Behar-Horenstein \& Niu, (2011) pentingnya untuk siswa mengembangkan keterampilan berpikirnya ketika terlibat dalam pembelajaran disekolah, karena guru akan memungkinkan siswanya terlibat dalam penilaian yang terencana. Hasil berpikir dapat berbentuk proses atau langkah-langkah dalam pemecahkan masalah. Dalam pemecahan masalah seringkali muncul kesalahan, kesalahan ini dapat diakibatkan oleh kesalahan berpikir yang dialami siswa.

Kesalahan berpikir menurut Secolsky et al., (2016) adalah bentuk-bentuk atau jenis-jenis argumen yang tidak tepat atau yang salah (incorrect argument) yang dihasilkan dari proses berpikir. Proses atau langkah ini dapat menjadi suatu masalah terhadap daya nalar, ketika terdapat ketidaksesuaian. Daya nalar yang kurang berkesesuaian dalam mennyelesaikan suatu masalah mengakibatkan siswa berpikir seolah-olah mengikuti proses penalaran, namun proses berpikir siswa sebenarnya belum sesuai dengan proses penalaran. Berpikir seperti inilah yang disebut berpikir pseudo (Subanji, 2016b). Pseudo sendiri secara bahasa berarti semu atau bukan sebenarnya, dalam penelitian ini pseudo merupakan jawaban yang seolah-olah benar atau salah, namun yang terjadi tidak sepenuhnya benar ataupun salah. Para peneliti banyak yang telah meneliti pseudo. Namun, mereka menggunakan istilah yang berbeda dalam menamainya, walaupun konten dan objek yang sama. Mereka sebenarnya merujuk ke pembahasan yang berfokus pada menjelaskan keberadaan proses berpikir pseudo (Subanji \& Maedi, 2015).

Pseudo terjadi saat memahami soal matematika, dimana kemampuan matematika yang dipahami masih mentah dan tidak berkesesuaian dengan kondisi nyata (Sa'dijah, Afriyani, Subanji, Muksar, \& Anwar, 2018). Bermacam-macam pseudo yang telah diteliti dengan konteks yang berbeda-beda. Adapun Vinner, (1997) konteks konseptual dan analitik sehingga Vinner menyebutnya sebagai pseudo-conceptual and pseudo-analytical. Subanji \& Nusantara, (2016) dalam konteks benar-salah pseudo tersebut dan memiliki sebutan sebagai pseudo-construction. Björklund \& Pramling, (2014) tidak jauh berbeda dengan konteks vinner menyebutnya sebagai pattern discernment and pseudo-conceptual. Karakteristik pseudo dalam pembelajaran matematika antara lain, siswa dalam belajar matematika, berpikir pseudo-conceptual dan pseudo-analytical, berpikir true-pseudo dan false-pseudo dan berpikir pseudo pada masalah yang kompleks (Wibawa, 2016). Konteks pseudo yang akan diteliti pada siswa-siswa sekolah 
dasar adalah pseudo-conceptual, true-pseudo dan false-pseudo. Pseudo terjadi pada siswa-siswa sekolah dasar, meskipun materimateri yang diajarkan merupakan materi dasar. Seperti pada penelitian Rafiah, Saufi, Aulia, \& Riadi, (2018) yang mencoba melihat pseudo pada operasi bilangan bulat. Berdasarkan penelitian Hayati, Subanji, \& Qohar, (2016) berpikir pseudo pada siswasiswa sekolah dasar terjadi akibat siswa berpikir secara spontan saat menyelesaikan masalah, siswa tidak mampu memilah informasi saat memecahkan masalah, siswa menggunakan prosedur yang semu saat menyelesaikan masalah dan siswa kurang memiliki pengetahuan awal tentang pemecahan masalah. Hal ini banyak dialami oleh para siswa sekolah dasar, dimana kurangnya pengamatan terhadap pseudo dan kesalahan berpikir lainnya sering kali terlewati untuk dibenahi. Padahal berpikir pseudo akan memperburuk prestasi siswa sehingga rendahnya prestasi tersebut dapat mencerminkan capaian domain konten dan juga capaian domain kognitif pada siswa (Subanji \& Nusantara, 2013).

Persentase pada bidang matematika kelas 4-8 pada instrumen pengukuran berturut-turut adalah $26 \%, 24 \%, 28 \%$, dan $32 \%$. Domain kognitif, meliputi pengetahuan (knowing), penerapan (applying) dan penalaran (reasoning), persentasenya pada instrumen berturut-turut adalah 32\%,24\%, dan 20\%, dan hasil persentase ini masih jauh dari hasil persentase internasional (Puspendik, 2016). Adanya hasil persentase ini harusnya membuat para ahli dibidang pendidikan untuk lebih fokus dalam menangani berpikir pseudo. Berpikir pseudo sering diakibatkan dari kurangnya pemahaman konsep, seperti pada penelitian Wibawa, (2013) yang menyebutkan bahwa pseudo terjadi pada siswa saat melakukan pemecahan masalah ditandai dengan awalan kesalahan siswa saat membuat asumsi (konsep) pada proses memahami masalah kemudian akibatnya siswa mengalami ketidaklengkapan dalam substruktur berpikir pada proses merencanakan cara penyelesaian. Menurut (Brown, 2016) konsep pecahan melibatkan berbagai asumsi dalam proses memahaminya. Menurut Prayitno, Purwanto, Subanji, \& Susiswo, (2018) pecahan merupakan salah satu bagian dari matematika yang sering digunakan sehari-hari. Selain itu, adanya tuntutan pada kurikulum 2013 menjadikan pecahan diharus sesegera mungkin untuk diajarkan di sekolah dasar. Hal ini juga dapat ditinjau bahwa hakikat matematika begitu juga pecahan, akan berhubungan dengan ide atau gagasan, struktur-struktur logika, kebenaran berdasarkan alasan logis, yang erat kaitannya dengan hipotesis, analogi, koneksi dan komunikasi, representasi, generalisasi, dan pemecahkan masalah (Sa'dijah, Rafiah, Gipayana, Qohar, \& Anwar, 2018). Konsep pecahan akan menjadi sarana yang sesuai untuk mengobservasi berpikir pseudo pada siswa.

Konsep pecahan dapat diajarkan dengan berbagai cara. Siswa memahami konsep berguna untuk menyelesaikan masalah, namun siswa yang tidak memahami konsep akan kesulitan ketika menghadapi masalah-masalah yang diberikan (Fithriani \& Hidayanto, 2018). Pembelajaran konsep pecahan di sekolah dasar dapat menggunakan media/alat peraga, melalui cerita dengan menggunakan objek nyata, dan balok pecahan, hal ini untuk menghindari kesalahpahaman pada pecahan senilai dan operasi pada pecahan (Henry Kurniawan et al., 2016). Pecahan menurut Van De Walle, (2010) adalah bilangan yang dapat ditulis dalam bentuk $\frac{a}{b}$, dimana a dan $\mathrm{b}$ adalah bilangan bulat dan $\mathrm{b} \neq 0$. Pada umumnya, pengajaran materi pecahan dengan pemahaman konsep akan dibutuhkan kesungguh-sungguhan dari guru dan siswa. Siswa dalam memahami pecahan saat pertama kali akan mengalami pemahaman matematika yang tidak berkesesuaian dengan pemahaman intuitif matematika yang mereka miliki (Strother, Brendefur, Thiede, \& Appleton, 2016). Oleh karena itu, pengajaran konsep pecahan menjadi fokus yang penting untuk dijadikan bahan penelitian.

Penelitian mengenai pengajaran konsep pecahan telah banyak dikaji. Penelitian-penelitian tentang pengajaran konsep pecahan seperti dalam tulisan (Holisin, 2009 ; Van De Walle, 2010 ; Clarke, Roche, \& Mitchell, 2011 ; Iuculano \& Butterworth, 2011; Muhsetyo, 2014 ; DeWolf, Bassok, \& Holyoak, 2015 ; Van Steenbrugge, Remillard, Verschaffel, Valcke, \& Desoete, 2015; Strother et al., 2016 ; Brown, 2016). Menurut Muhsetyo, (2014) pengajaran konsep operasi pecahan sering kali digunakan cara membandingkan pecahan dengan menggunakan kelipatan persekutuan terkecil. Hal ini menunjukan bahwa pembelajaran pecahan belum dapat dilakukan sebelum adanya pembelajaran tentang kelipatan persekutuan terkecil. Selain itu, adanya pemahaman konsep pecahan pada siswa yang masih bersifat hafalan. Hal ini ditunjukkan dengan pernyataan siswa tentang konsep pecahan dengan menyebutkan konsep secara simbolis (Permadi \& Irawan, 2016). Oleh karena itu, pembelajaran konsep pecahan yang kurang tepat dapat mengakibatkan berpikir pseudo siswa. Konsep pecahan yang memiliki berbagai asumsi dalam pengajarannya di sekolah dasar akan menjadi sangat penting untuk diteliti. Sehingga dalam penelitian ini akan ditemukan kesalahan-kesalahan siswa dalam memahami konsep pecahan. Kekeliruan konsep pecahan dapat ditandai oleh adanya skema dominan dengan penggunaan prosedur standar yang tidak sesuai sehingga menghasilkan skema terkait (Kurniawan, Sutawidjaja, As'Ari, \& Muksar, 2018).

\section{METODE}

Penelitian ini dilakukan pada Oktober 2018 di SDN 1 Sumbersari kota Malang. Penelitian yang dilakukan merupakan penelitian deskiptif-kualitatif, dimana hasil pekerjaan siswa dianalisis berdasarkan terjadinya pseudo. Terdapat 28 siswa kelas IV di SDN 1 Sumbersari Kota Malang diberikan masalah terkait dengan pecahan. Dipilihnya kelas IV karena para siswa telah diajarkan konsep-konsep pecahan. Hal ini agar setiap jawaban siswa yang telah belajar konsep-konsep pecahan dapat diamati pseudonya, kemudian tiga siswa dipilih untuk menjadi subjek. Subjek diberikan masalah yang lain untuk mengetahui lebih mendalam pseudo yang terjadi. Subjek diobservasi pseudonya melalui instrumen yang diberikan. 
Instrumen yang digunakan dalam penelitian ini berupa soal 2 dan wawancara. Pada tabel 2 soal nomor 2 digunakan untuk mengetahui jawaban siswa dalam memahami konsep-konsep pecahan. Sedangkan wawancara digunakan untuk mengetahui alasan jawaban siswa, dimana alasan ini merupakan pemahaman siswa tentang konsep-konsep pecahan. Wawancara ini dilakukan ketika siswa telah mengerjakan soal 2. Adanya soal 2 dan wawancara menunjukan bahwa penelitian ini harus diproses menjadi beberapa tahap.

Tahap-tahap yang dilakukan agar tercapainya hasil yang memuaskan. Tahap pertama ialah pemberian soal 1 kepada 28 siswa atau satu kelas, hal ini berguna untuk memperoleh subjek dengan membandingkan pseudo yang terjadi. Tahap kedua ialah memilih subjek yang mengalami masing-masing pseudo dan memberikan soal 2, Hal ini digunakan mengetahui pseudo masih tetap terjadi saat siswa bertemu masalah yang berkaitan dengan konsep-konsep pecahan. Tahap ketiga ialah wawancara mengenai hasil soal 2, hal ini berguna untuk menganalisis jawaban siswa dan mengetahui dengan pasti pseudo yang terjadi. Tahap keempat ialah menyeleksi jawaban-jawaban siswa yang berkesesuaian dengan wawancara, untuk mewakili terjadinya pseudo-conceptual, true-pseudo dan false-pseudo. Analisis data pada penelitian ini dilakukan dengan cara mengelompokkan jawaban siswa berdasarkan hasil instrumen yang diperoleh.

Tabel 1. Soal 1

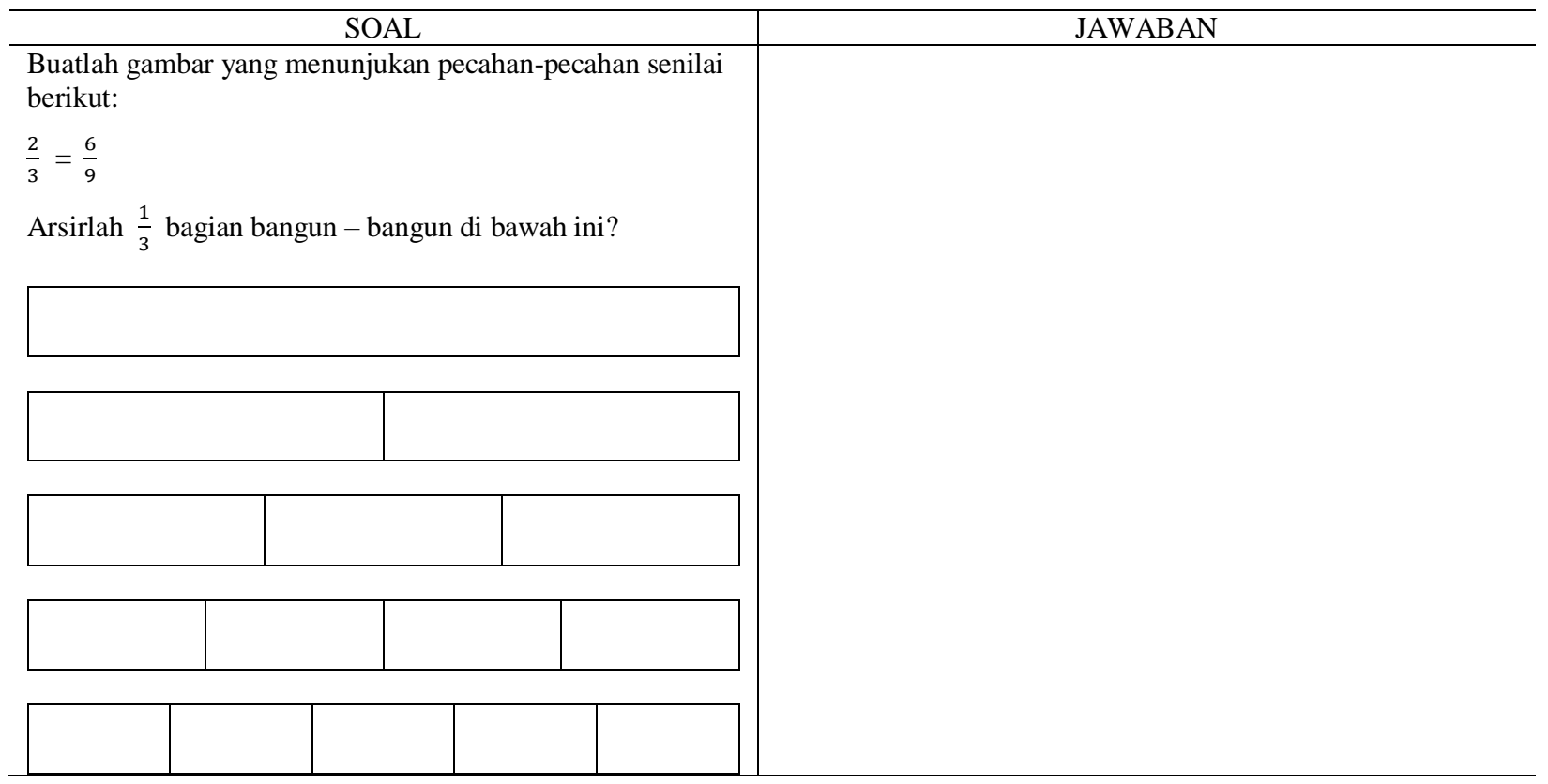

Tabel 2. Soal 2

\begin{tabular}{l|l|l}
\hline No & \multicolumn{1}{|c|}{ Soal } & Jawaban \\
\hline 1 & Gambarlah $\frac{1}{2}=\frac{2}{4} !$ & \\
2 & Gambarlah $\frac{2}{3}<\frac{3}{4} !$ & \\
3 & Gambarlah $\frac{2}{3} \times \frac{1}{2}=\frac{2}{6} !$ & \\
4 & Gambarlah $\frac{1}{3}: \frac{1}{2}=\frac{2}{3} !$ & \\
\hline
\end{tabular}

\section{HASIL}

Tahapan pertama yang dilakukan ialah memberikan soal 1 pada 28 siswa. Hasil dari soal 1 yang dikerjakan oleh 28 siswa menunjukan bahwa adanya pemahaman yang semu ( $p$ seudo). Hasil pekerjaan siswa terlihat adanya pseudo yang terjadi, dimana pengelompokan hasil jawaban siswa dapat dilihat pada tabel 3. 
Tabel 3. Pengelompokan Soal 1 Pertanyaan Pertama

\begin{tabular}{|c|c|c|c|c|c|}
\hline Pertanyaan & $\begin{array}{c}\text { Pseudo } \\
\text { Conceptual }\end{array}$ & $\begin{array}{c}\text { True- } \\
\text { Pseudo }\end{array}$ & $\begin{array}{l}\text { False- } \\
\text { Pseudo }\end{array}$ & Benar & Salah \\
\hline $\begin{array}{l}\text { Buatlah gambar yang menunjukan pecahan-pecahan senilai } \\
\text { berikut: } \\
\frac{2}{3}=\frac{6}{9}\end{array}$ & 3 & 24 & 0 & 0 & 1 \\
\hline
\end{tabular}

Contoh-contoh hasil jawaban siswa dapat dilihat pada Gambar 1, 2, 3 dan 4. Pada gambar 1 dan 2 siswa mencoba menggambarkan pecahan $\frac{2}{3}$ yang senilai dengan $\frac{6}{9}$ melalui menggambar terlebih dahulu pecahan $\frac{2}{3}$ kemudian menggambar pecahan $\frac{6}{9}$.

Pada hasil soal 1 tentang pecahan senilai, siswa tidak tampak memahami bahwa bangun yang dibuat harus sama (kongruen). Jawaban seperti ditunjukkan pada Gambar 1 dan 2, dimana pada kedua gambar memiliki ukuran bangun yang berbeda dan bagian diarsir tidak memiliki ukuran yang sama (kongruen). Hal ini mengindikasikan terjadinya true-pseudo, sebagaimana pernyataan Subanji \& Nusantara, (2016) true-pseudo adalah kondisi dimana siswa mampu menyelesaikan masalah matematika yang seolah-olah benar, namun tidak sepenuhnya benar dalam pemahaman konsep atau penalaran. Dengan demikian, pada gambar 1 dan 2 termasuk true-pseudo, sedangkan pada gambar 3 dan 4 berbeda kondisi yang dialami.

Kondisi yang dialami pada gambar 3 tampak jawaban siswa mencoba menggambar bangun dengan ukuran yang sama namun siswa tidak menjawab berdasarkan konsep menggambar pecahan. Ketidaksesuaian konsep ini yang mengakibatkan pseudo dalam pemahaman siswa, pemahaman konsep yang dangkal mengindikasikan terjadinya pseudo conceptual. Karena terjadinya pemahaman konsep yang dangkal diakibatkan adanya proses berpikir siswa yang tidak terkontrol dan berkesesuaian dengan konsep, sehingga siswa tersebut termasuk kedalam berpikir pseudo conceptual. Pada gambar 4 siswa tidak mencoba untuk menggambarkan pecahan, hal ini menandakan bahwa siswa benar-benar tidak memahami konsep pecahan. Jawaban gambar 4 menunjukkan tidak terjadi berpikir pseudo siswa, sehingga jawaban siswa tersubut termasuk kedalam jawaban salah.

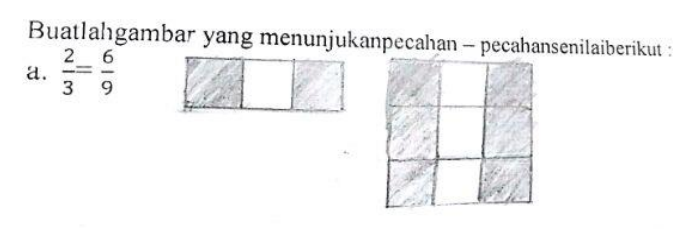

Gambar 1. Berpikir True-Pseudo

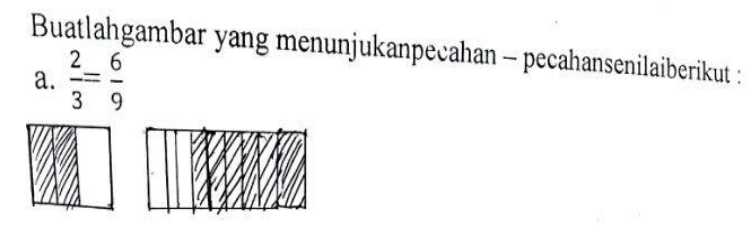

Gambar 2. Berpikir True-Pseudo

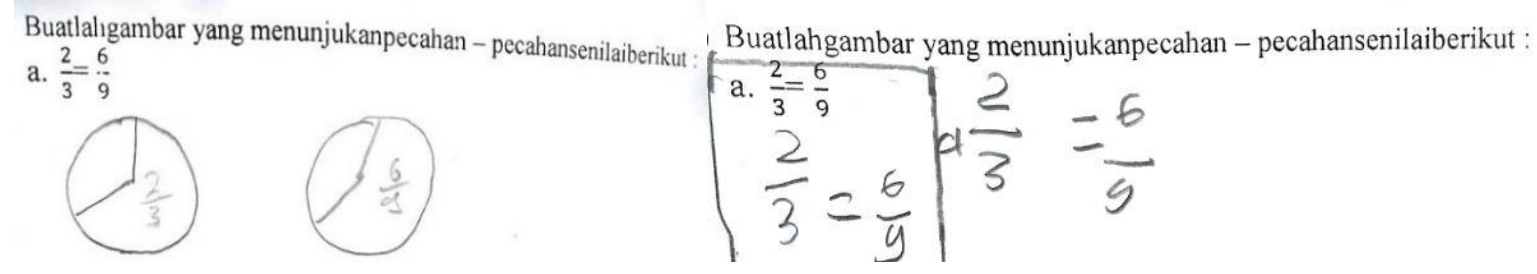

Gambar 3. Berpikir Pseudo Conceptual

Gambar 4. Salah

Pada hasil dari soal 1 berikutnya, ada 28 siswa menunjukan bahwa adanya pemahaman yang semu (pseudo). Hasil pekerjaan siswa terlihat adanya pseudo yang terjadi, dimana pengelompokan hasil jawaban siswa dapat dilihat pada Tabel 4 . Pada Tabel 4 ditunjukkan tentang berpikir pseudo pada 28 siswa, hasilnya dari 28 siswa tersebut tidak ada siswa yang menjawab "benar" secara menyeluruh namun terdapat 17 siswa yang berpikir false-pseudo dan 11 siswa yang "salah". 
Tabel 4. Pengelompokan Soal 1 Pertanyaan Kedua

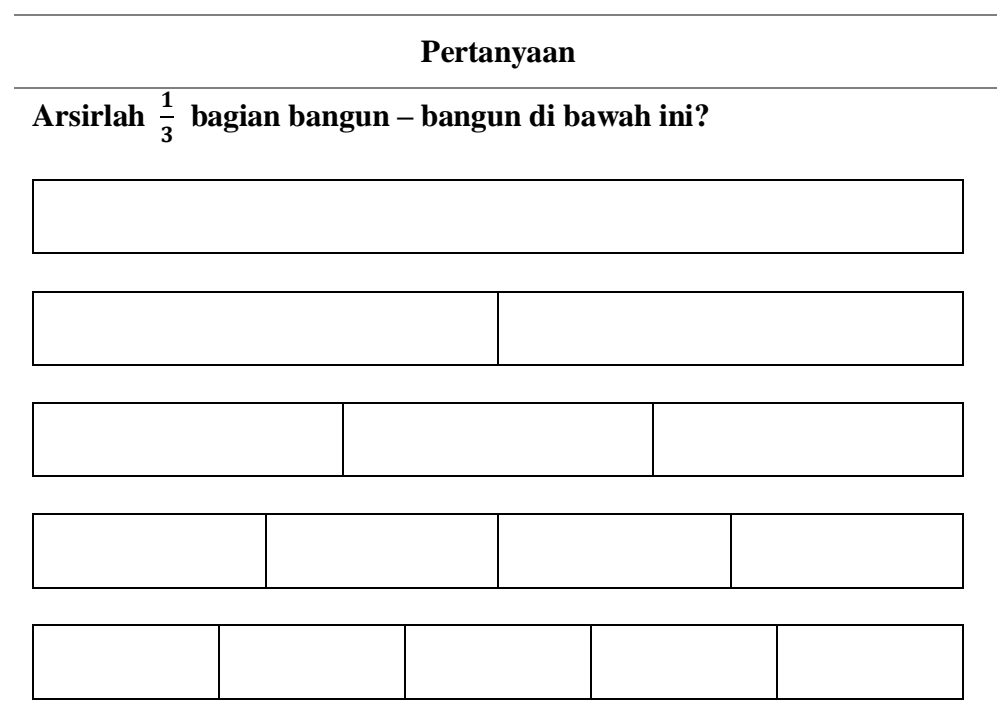

\begin{tabular}{ccccc}
$\begin{array}{c}\text { Pseudo } \\
\text { Conceptual }\end{array}$ & $\begin{array}{c}\text { True- } \\
\text { Pseudo }\end{array}$ & $\begin{array}{c}\text { False- } \\
\text { Pseudo }\end{array}$ & Benar & Salah \\
\hline
\end{tabular}

0

0

17

0

11

Contoh hasil jawaban siswa dapat dilihat pada gambar 5, 6, 7 dan 8. Siswa awalnya mencoba mengidentifikasi $\frac{1}{3}$ bagian dari bangun tersebut (Gambar 5), sehingga bagian yang diarsir mencoba merepresentasikan $\frac{1}{3}$ bagian. Selanjutnya soal coba dijelaskan sebagai bentuk refleksi.

Pada hasil soal 1 tentang mengarsir $\frac{1}{3}$ bagian dari bangun, Soal menjelaskan bahwa $\frac{1}{3}$ bagian yang harus diarsir adalah $\frac{1}{3}$ bagian pada setiap bangun dan diberikan bantuan tambahan petunjuk, gunakan bantuan bangun yang terpecah menjadi tiga bagian. Hal ini digunakan sebagai bentuk refleksi agar siswa memahami maksud dari soal, dan salah satu hasilnya seperti yang tampak pada gambar 6. Terdapat 17 siswa menunjukkan bahwa adanya false-pseudo yang terjadi pada kondisi tersebut. Sehingga 17 siswa menujukkan mengalami kondisi dimana mereka seolah-olah salah dalam memberikan jawaban meskipun sebenarnya mereka mampu memberikan jawaban secara benar setelah refleksi. Sementara itu, pada gambar 7 dan 8 bukan merupakan kondisi pseudo.

Coba Arsir $\frac{1}{3}$ bagian bangun - bangun di bawah ini?
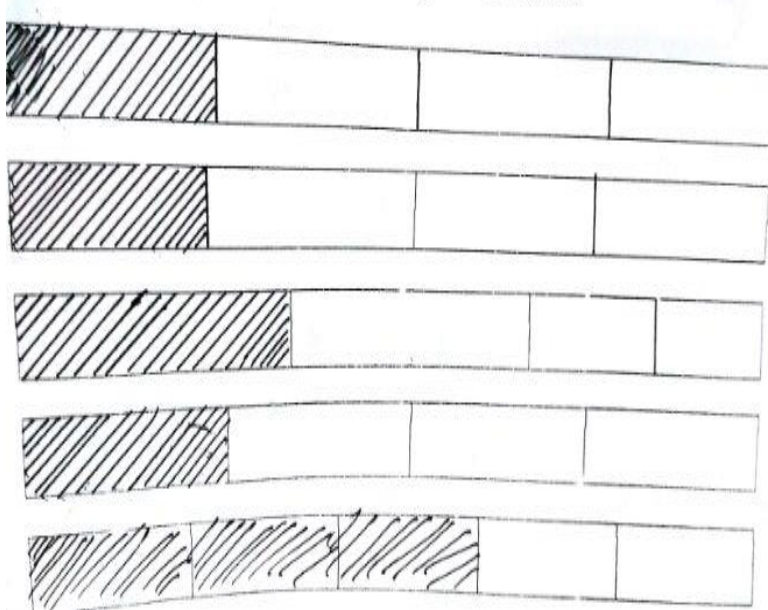

Gambar 5. False-pseudo sebelum refleksi
Coba Arsirlah $\frac{1}{3}$ bagian bangun - bangun di bawah ini?

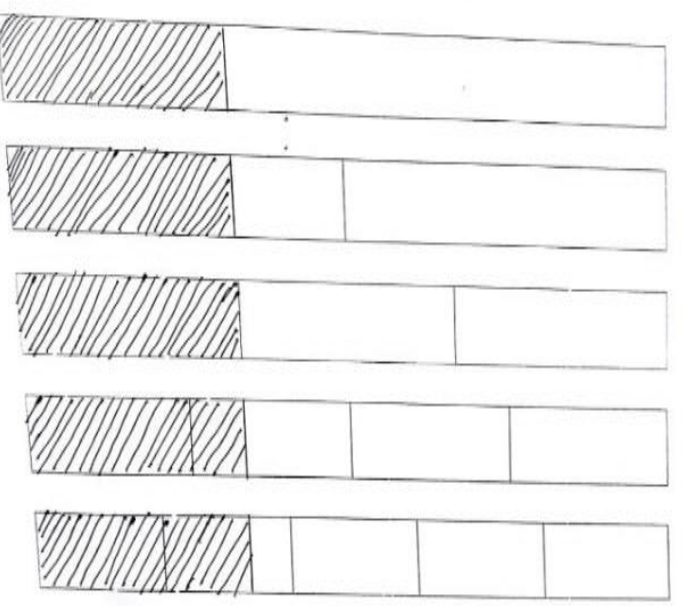

Gambar 6. False-pseudo setelah refleksi 
Hasil menunjukkan bahwa gambar 7 merupakan contoh dari pekerjaan awal siswa yang mencoba mengarsir $\frac{1}{3}$ bagian, sedangkan pada gambar 8 merupakan hasil dari pekerjaan siswa setelah diberikan refleksi. Jawaban siswa pada gambar 8 menunjukkan bahwa jawaban siswa masih salah meskipun telah diberikan refleksi. Siswa pada kondisi ini bukan menunjukkan pada kondisi pseudo, tetapi proses berpikir siswa itu memang "salah sungguhan".

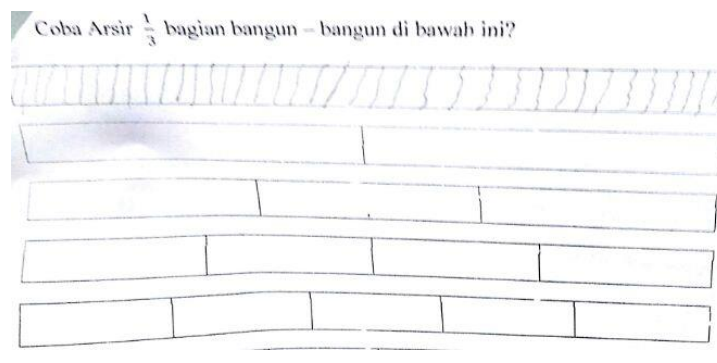

Gambar 7. Jawaban salah sebelum refleksi

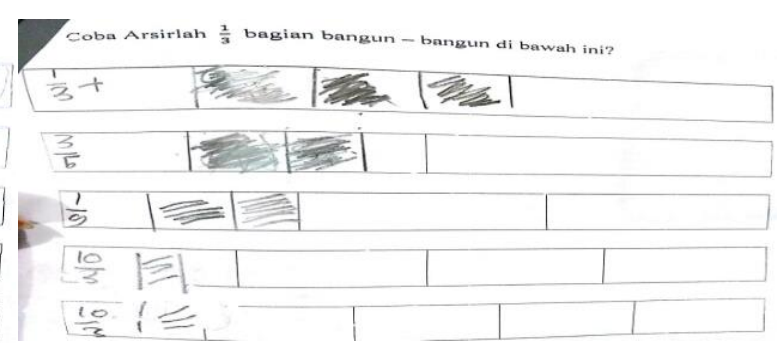

Gambar 8. Jawaban salah setelah refleksi

Tahap kedua, ketiga, dan keempat akan dibahas secara bersamaan, karena pada ketiga tahap ini memang saling berkaitan. Tahap kedua ialah memilih subjek yang mengalami masing-masing pseudo dan memberikan soal 2 kepada masing-masing subjek diberikan soal 2 (Tabel 2). Subjek 1 merupakan subjek berpikir pseudo conceptual yang telah dipilih, Subjek 2 merupakan subjek berpikir true-pseudo yang telah dipilih dan Subjek 3 merupakan subjek berpikir false-pseudo yang telah dipilih. Jawaban subjek 1 dapat dilihat pada gambar 9, Jawaban subjek 2 dapat dilihat pada gambar 10, dan jawaban subjek 3 dapat dilihat pada Gambar 11 .

Tahap kedua subjek 1 dalam menjawab masalah nomor 1 tampak berpikir pseudo conceptual, dimana jawaban tidak disertai arsiran yang mewakili nilai pembilang merupakan salah satu masalah dalam pemahaman pecahan. Subjek 1 selanjutnya mencoba mengerjakan masalah nomor 2, subjek 1 mengerjakan dengan bangun persegi panjang dan terdapat arsiran pada bangun tersebut (gambar 9). Berikut wawancara antara peneliti dengan subjek 1.

$\mathrm{P}:$ Kenapa nomor 1 lingkarannya tidak diarsir?

S1: Karena sudah diberi angka ( $\frac{1}{2}$ atau $\left.\frac{2}{4}\right)$, pak.

$\mathrm{P}$ : Kenapa nomor 2 persegi panjangnya diarsir?

S1: Biar jadi $\frac{2}{3}$ dan $\frac{3}{4}$, pak

$\mathrm{P}:$ Kenapa didalam persegi panjang tidak diberi angka $\left(\frac{2}{3}\right.$ atau $\left.\frac{3}{4}\right)$ saja?

S1: Karena angkanya tidak cukup.

Pseudo conceptual yang terjadi pada subjek 1 diakibatkan adanya pemahaman subjek 1 tentang anggapan menaruh angka pada lingkaran yang mewakili nilai pecahan, sehingga tidak dibutuhkan arsiran. Pada masalah nomer 2 , subjek 1 memberi arsiran pada persegi panjang dan tidak menaruh angka didalam persegi panjang. Pada masalah nomer 3, subjek 1 diberikan masalah tentang bagaimana menggambar bentuk $\frac{2}{3} \times \frac{1}{2}=\frac{2}{6}$. Jawaban subjek 1 menunjukkan gambar $\frac{2}{3}, \frac{1}{2}$ dan $\frac{2}{6}$, tanpa adanya keterikatan antara pecahan-pecahan tersebut dengan konsep perkalian pecahan. Pada masalah nomer 4, subjek 1 diberikan masalah tentang bagaimana menggambar bentuk $\frac{1}{3}: \frac{1}{2}=\frac{2}{3}$. Jawaban subjek 1 tidak jauh berbeda dengan menggambar perkalian pecahan. Subjek 1 menunjukkan gambar $\frac{1}{3}, \frac{1}{2}$ dan $\frac{2}{3}$, tanpa adanya keterikatan antara pecahan-pecahan tersebut dengan konsep pembagian pecahan. Jawaban subjek 1 pada masalah nomor 3 dan 4 menunjukkan angka masih dituliskan di luar persegi panjang, sehingga subjek 1 yang berpikir pseudo conceptual atau mengalami kesalahan dalam pemahaman konsep pecahan.

Subjek 1 memiliki pemahaman bahwa penulisan angka merupakan bagian yang terpenting dalam interpretasi pecahan. Subjek 1 bahkan menganggap penulisan angka lebih penting daripada mengarsir bangun. Sehingga interpretasi pembilang pada gambar yang telah dibuat akan tidak dapat dipahami. Mengarsir beberapa bagian sebagai bentuk interpretasi pembilang dilakukan setelah subjek 1 memiliki anggapan bahwa angka tidak dapat dituliskan didalam bangun sehingga subjek 1 dengan terpaksa mengarsir bangun tersebut. Subjek 1 secara pemahaman menggambar pecahan teridentifikasi tidak memahami konsep sehingga subjek 1 berada pada kondisi berpikir pseudo conceptual. 


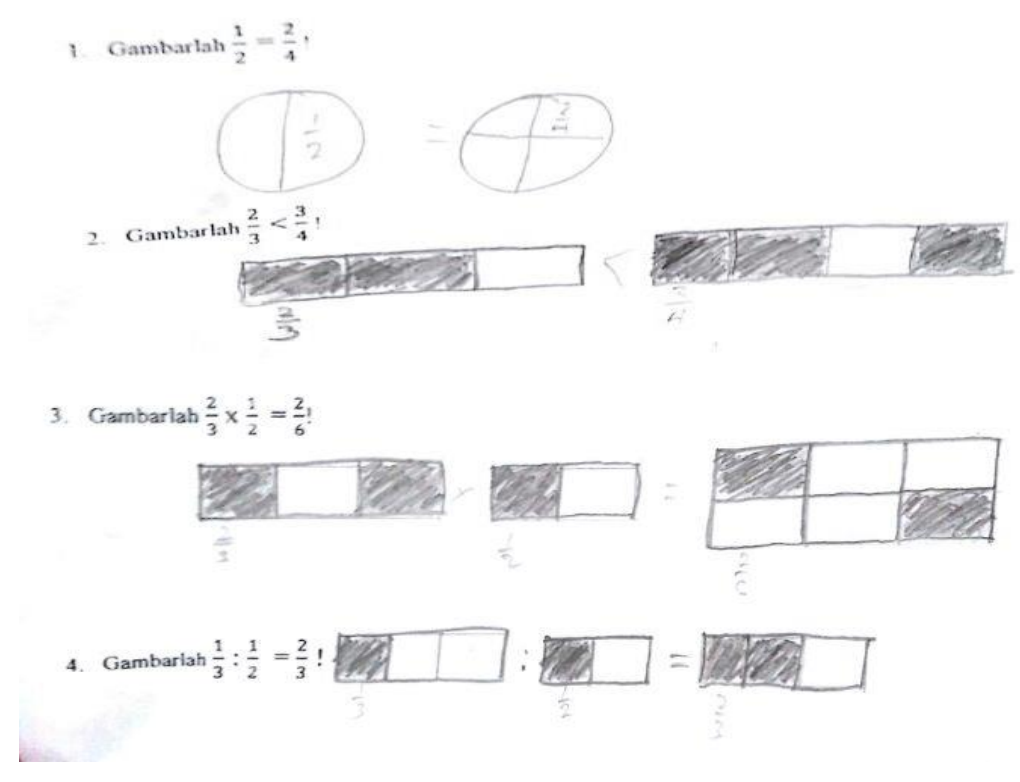

Gambar 9. Jawaban Subjek 1 (Berpikir Pseudo Conceptual)

Subjek 2 dalam menjawab masalah nomer 2 tampak berpikir true-pseudo (Gambar 10). Jawaban masalah nomor 1 tampak seolah-olah benar, namun kalau diamati berdasarkan konsep pecahan maka ukuran bangun $\frac{2}{4}$ lebih besar daripada $\frac{1}{2}$ tidak sesuai dengan konsep pecahan senilai. Berikutnya, subjek 2 mencoba menyelesaikan masalah nomer 2 dengan menggambarkan pecahan $\frac{2}{3}$ dan $\frac{3}{4}$, saat ditanyakan kenapa ukuran bangun $\frac{3}{4}$ lebih besar dari $\frac{2}{3}$ subjek menjawabnya sebagai berikut.

$\mathrm{P}:$ : Kenapa nomor 1 bangun $\frac{2}{4}$ lebih besar dari pada $\frac{1}{2}$ ?

S2 : Karena $\frac{1}{2}$ ada dua kotak kalau $\frac{2}{4}$ ada 4 kotak.

$\mathrm{P}$ : Kenapa ukurannya tidak disamakan saja?

S2 : gak bisa, karena 4 kotak lebih banyak dari 2 kotak

$\mathrm{P}:$ Kenapa nomer 2 bangun $\frac{3}{4}$ lebih besar dari pada $\frac{2}{3}$ ?

S2 : Karena 4 kotak, satunya 3 kotak.

Hasil wawancara subjek 2 menunjukkan tentang berpikir true-pseudo, dimana seolah-olah jawaban subjek 2 benar namun jawabannya tidak berkesesuaian dengan konsep pecahan. Subjek 2 tidak memahami tentang ukuran bangun yang dibuat pada pecahan senilai harus sama (kongruen). Setelah membuat ukuran yang sama maka bangun-bangun dapat dipecah sebanyak masing-masing penyebut. Pada masalah nomor 3 , subjek 2 diberikan masalah tentang bagaimana menggambar bentuk $\frac{2}{3} \times \frac{1}{2}=\frac{2}{6}$. Jawaban subjek 2 menunjukkan gambar $\frac{2}{3}, \frac{1}{2}$ dan $\frac{2}{6}$, tanpa adanya keterikatan antara pecahan-pecahan tersebut dengan konsep perkalian pecahan. Pada masalah nomer 4 , subjek 2 diberikan masalah tentang bagaimana menggambar bentuk $\frac{1}{3}: \frac{1}{2}=\frac{2}{3}$. Subjek 2 menjawabnya dengan menggambar pembagian pecahan dengan menunjukkan gambar $\frac{1}{3}, \frac{1}{2}$ dan $\frac{2}{3}$, tanpa adanya keterikatan antara pecahan-pecahan tersebut dengan konsep pembagian pecahan.

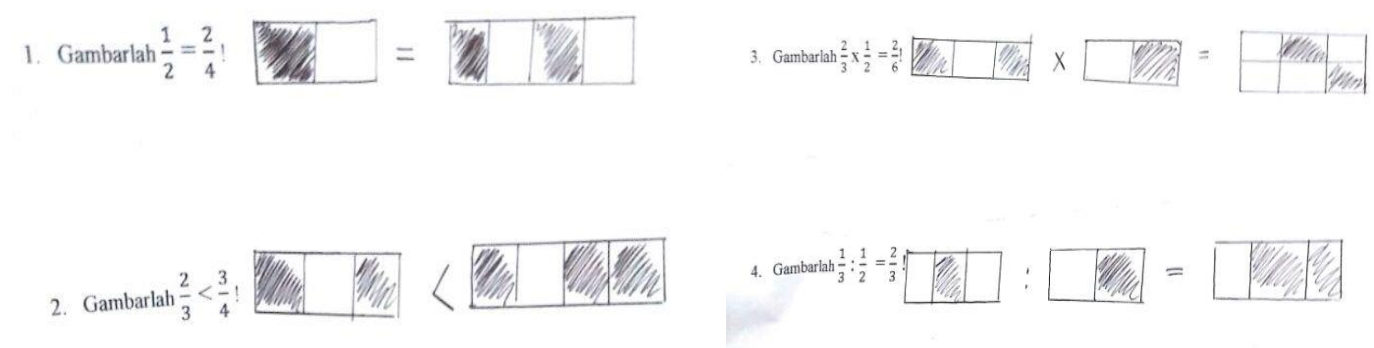

Gambar 10. Jawaban Subjek 2 (Berpikir True-Pseudo) 
Khusus subjek 3, wawancara dilakukan bersamaan dengan mengerjakan soal 2. Hal ini dikarenakan subjek 3 merupakan siswa yang mengalami false-pseudo. Subjek 3 dalam menjawab masalah nomer 1 terlihat berpikir false-pseudo (gambar 11). Wawancara secara bersamaan sangat perlu dilakukan pada subjek 3, karena wawancara sebagai bentuk refleksi terhadap subjek 3. Jawaban masalah nomer 1, subjek 3 nampak akan menggambar bangun dengan ukuran yang berbeda, sehingga tidak berkesesuaian dengan konsep pecahan senilai. Setelah subjek 3 diberi pertanyaan "kenapa ukurannya bangunnya berbeda? Kan pecahan senilai". Berikutnya, subjek 3 menghapus gambar dan mencoba menggambar bangun $\frac{1}{2}$ dan $\frac{2}{4}$ dalam ukuran yang sama. Wawancara lebih lengkap dengan subjek 3 dipaparkan sebagai berikut.

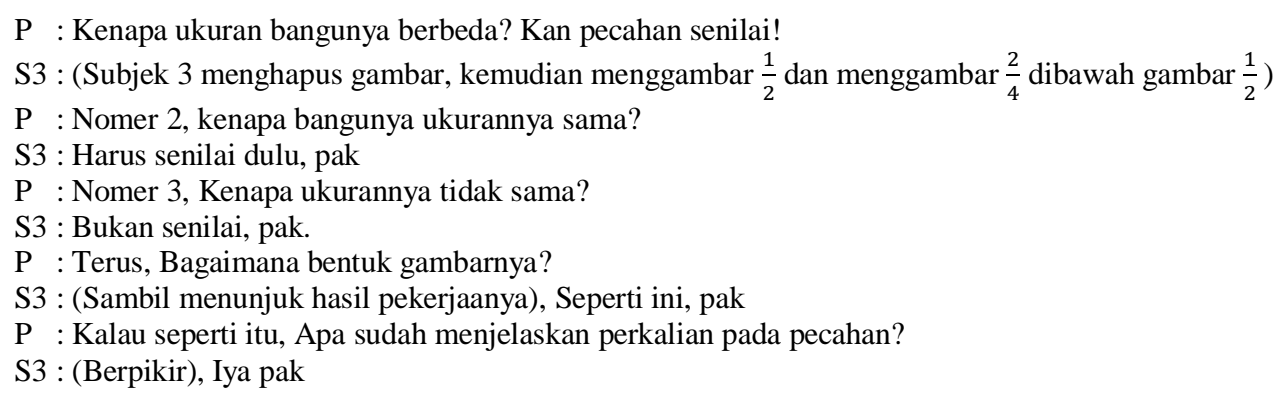

Hasil wawancara subjek 3 menunjukkan tentang berpikir false-pseudo, dimana subjek 3 menghapus gambar pecahan setelah diberi refleksi tentang pecahan senilai. Sehingga subjek yang berpikir false-pseudo memperoleh jawaban benar setelah adanya refleksi. Subjek 3 juga menerapkan saat mengerjakan masalah nomer 2. Namun pada masalah nomor 3 dan 4, subjek 3 tidak dapat memahami konsep menggambar perkalian dan pembagian. Sehingga, ketika subjek 3 diberikan masalah tentang bagaimana menggambar bentuk $\frac{2}{3} \times \frac{1}{2}=\frac{2}{6}$. Jawaban subjek 3 menunjukkan gambar $\frac{2}{3}, \frac{1}{2}$ dan $\frac{2}{6}$, tanpa adanya keterikatan antara pecahan-pecahan tersebut dengan konsep perkalian pecahan. Pada masalah nomor 4, subjek 3 diberikan masalah tentang bagaimana menggambar bentuk $\frac{1}{3}: \frac{1}{2}=\frac{2}{3}$. Subjek 3 menjawabnya dengan menggambar pembagian pecahan dengan menunjukkan gambar $\frac{1}{3}, \frac{1}{2}$ dan $\frac{2}{3}$, tanpa adanya keterikatan antara pecahan-pecahan tersebut dengan konsep pembagian pecahan.

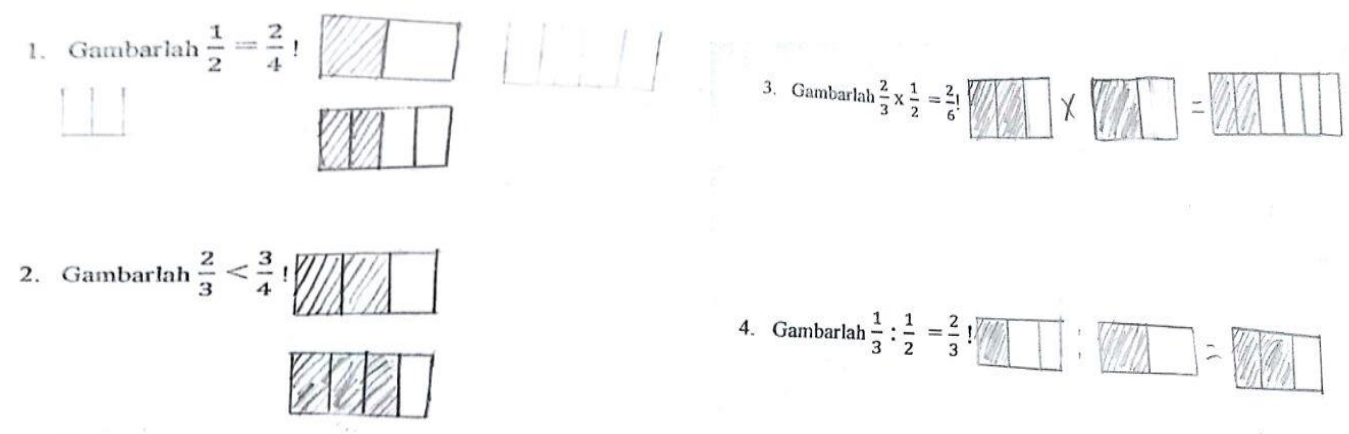

Gambar 11. Jawaban Subjek 3 (Berpikir False-Pseudo)

\section{PEMBAHASAN}

Berpikir pseudo siswa pada konsep pecahan yang akan dibahas akan dikelompokkan menjadi tiga jenis. Pengelompokan berpikir pseudo siswa didasarkan pada jenis-jenis berpikirnya. Sehingga siswa yang berpikir pseudo tersebut dikelompokan menjadi pseudo conceptual, true-pseudo dan false-pseudo.

Berpikir pseudo siswa pada konsep pecahan saat siswa menggambarkan pecahan senilai, terjadi berpikir pseudo conceptual tampak pada jawaban siswa yang mencoba menggambar bangun dengan ukuran yang sama, namun siswa tidak menjawab berdasarkan konsep menggambar pecahan. Ketidaksesuaian konsep ini yang mengakibatkan pseudo dalam pemahaman siswa, pemahaman konsep yang dangkal mengindikasikan terjadinya pseudo conceptual. Karena terjadinya pemahaman konsep yang dangkal diakibatkan adanya proses berpikir siswa yang tidak terkontrol dan berkesesuaian dengan konsep, sehingga siswa tersebut termasuk kedalam berpikir pseudo conceptual (Vinner, 1997). Siswa mengalami berpikir pseudo conceptual pada konsep pecahan, disaat siswa menggambarkan pecahan senilai dan pertidaksamaan pecahan. Dimana konsep menggambarkan pecahan dengan menggunakan bentuk persegi panjang seharusnya dilakukan dengan cara memecah persegi panjang tersebut sebanyak penyebut dan mengarsir sebanyak pembilang (Alamsyah \& Subanji, 2018). Namun jawaban siswa tidak disertai arsiran yang mewakili nilai pembilang merupakan salah satu masalah dalam pemahaman pecahan (Strother et al., 2016). Begitu juga jawaban siswa pada masalah nomor 3 dan 4 menunjukkan angka masih dituliskan diluar persegi panjang, sehingga siswa yang berpikir 
pseudo conceptual atau mengalami kesalahan dalam pemahaman konsep pecahan (Vinner, 1997). Pseudo conceptual yang terjadi diakibatkan oleh kesalahan dalam konsep pecahan, hal ini dikarenakan siswa tidak dapat menggunakan informasi yang telah diajarkan dan siswa memiliki pemahaman sendiri (Nur, 2009). Sehingga siswa secara pemahaman menggambar pecahan teridentifikasi tidak memahami konsep dan berada pada kondisi berpikir pseudo conceptual (Björklund \& Pramling, 2014).

Berpikir pseudo siswa pada konsep pecahan saat siswa menggambarkan pecahan senilai, terjadi berpikir true-pseudo ketika jawaban siswa terlihat benar, hal ini diakibatkan karena siswa mampu menggambarkan masing-masing pecahan. Namun berdasarkan konsep pecahan senilai, dimana terdapat ukuran bangun yang sama dibagi menjadi sebanyak masing-masing penyebut dan pembilang sebagai arsiran akan memiliki ukuran yang sama (kongruen) (Kurniawan et al., 2018). Hasil jawaban siswa masih belum sesuai dengan konsep menggambarkan pecahan. Jawaban siswa hanya berkesesuaian dengan konsep pecahan biasa bangun dipecah menjadi sebanyak penyebut dan diarsir sebanyak pembilang (Brown, 2016). Berpikir pseudo siswa pada konsep pecahan saat siswa menggambarkan pertidaksamaan pecahan, terjadi berpikir true-pseudo ketika jawaban siswa nampak benar karena siswa mampu menggambarkan masing-masing pecahan. Namun, jawaban siswa tidak menujukkan gambar salah satu pecahan lebih besar atau lebih kecil daripada pecahan lainnya. Sehingga argumennya tidak berkesesuaian dengan konsep pecahan (Subanji \& Maedi, 2015). Hal ini menunjukkan bahwa subjek mengalami berpikir true-pseudo, dimana jawaban subjek tampak benar, namun tidak benar secara keseluruhan jika berdasarkan konsep pecahan (Subanji \& Nusantara, 2016).

Siswa mengalami berpikir false-pseudo pada konsep pecahan, disaat siswa menggambarkan pecahan senilai dalam bentuk persegi panjang yang terpecah menjadi bermacam-macam bagian. Awalnya siswa tidak mampu menggambarkan pecahan senilai dalam bentuk persegi panjang yang terpecah menjadi bermacam-macam bagian. Namun, saat siswa diberikan bantuan tambahan petunjuk yang berguna untuk pemberian refleksi dalam memahami soal, siswa akhirnya mampu menjawab dengan benar. Hal tersebut menunjukkan bahwa siswa mengalami kondisi dimana mereka seolah-olah salah dalam memberikan jawaban meskipun sebenarnya mereka mampu memberikan jawaban secara benar setelah refleksi (Wibawa, 2013). Sedangkan jawaban siswa yang masih salah meskipun telah diberikan refleksi, maka pada kondisi ini siswa bukan menunjukan kondisi pseudo, akan tetapi proses berpikir siswa itu memang "salah sungguhan" (Wibawa, 2016). Siswa mengalami berpikir false-pseudo pada konsep pecahan, disaat siswa menggambarkan pecahan senilai dan pertidaksamaan pecahan. Subanji, (2016b) menyebutkan bahwa refleksi terhadap subjek perlu dilakukan secara maksimal sehingga pada akhirnya subjek dapat menyadari bahwa jawaban yang diperoleh masih kurang sesuai. Wawancara siswa menunjukkan tentang berpikir false-pseudo, dimana siswa menghapus gambar pecahan setelah diberi refleksi tentang pecahan senilai sehingga subjek yang berpikir false-pseudo memperoleh jawaban benar setelah adanya refleksi (Subanji \& Nusantara, 2016).

Interpretasi merupakan salah satu hal penting dalam pembelajaran pecahan. Pecahan akan menjadi abstrak tanpa adanya interpretasi, sama halnya dengan matematika pada umumnya. Interpretasi dalam menggambarkan pecahan harusnya dimulai dari membuat gambar yang memiliki ukuran yang sama atau kongruen dan bangun yang diarsir memiliki ukuran yang sama (Kurniawan et al., 2016), jika tidak maka pecahan yang sama akan memiliki ukuran berbeda seperti pada gambar 12. Hal ini akan mengakibatkan multi penafsiran dalam memahami pecahan sehingga interpretasi saat menjawab soal 2 yang sesuai dengan konsep pecahan akan dijabarkan pada gambar 13.

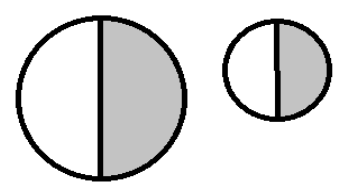

Gambar 12. Setengah tidak senilai dengan setengah lainnya

1. Gambarlah $\frac{1}{2}=\frac{2}{4}$ !

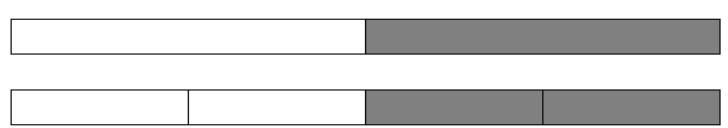

2. Gambarlah $\frac{2}{3}<\frac{3}{4}$ !

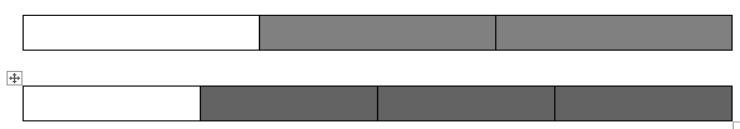

3. Gambarlah $\frac{2}{3} \times \frac{1}{2}=\frac{2}{6}$ !

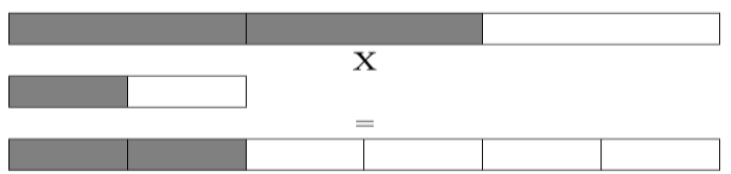

4. Gambarlah $\frac{1}{3}: \frac{1}{2}=\frac{2}{3}$ !

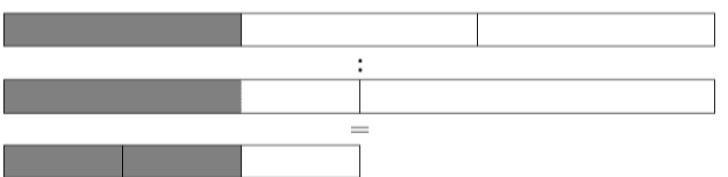

Gambar 13. Jawaban soal 2 berdasarkan konsep 
Nomor 1 pada soal 2 mencoba mengasah kemampuan siswa untuk menggambarkan pecahan senilai $\frac{1}{2}=\frac{2}{4}$, dimana pada tahap awal yang perlu diperhatikan adalah ukuran awal kedua bangun. Awal menggambar kedua bangun harus memiliki ukuran yang sama (kongruen). Ketika ukuran bangun awal tidak sama maka pecahan-pecahan yang sama tidak akan memiliki ukuran yang sama pada bangun yang berbeda ukuran (gambar 12). Tahap selanjutnya adalah memecah bangun-bangun menjadi sebanyak penyebut dan hasilnya harus memiliki ukuran yang sama. Tahap terakhir, bangun-bangun yang diarsir harus memiliki ukuran yang sama. Karena hal ini merupakan bentuk interpretasi dari senilai (gambar 13) (Van De Walle, 2010).

Nomor 2 pada soal 2 mencoba mengasah kemampuan siswa untuk menggambarkan pecahan $\frac{2}{3}<\frac{3}{4}$. Saat mencoba menjawab nomor 2 ukuran bangun awal menggunakan bangun yang sama. Kemudian menggambarkan pecahan $\frac{2}{3}$ dan $\frac{3}{4}$ sesuai konsep pecahan, terakhir, akan terlihat hasil interpretasi $\frac{2}{3}<\frac{3}{4}$ (gambar 13).

Nomor 3 dan 4 pada soal 2 mencoba mengasah kemampuan siswa untuk menggambarkan pecahan $\frac{2}{3} \times \frac{3}{4}=\frac{2}{6}$ dan $\frac{1}{3}: \frac{1}{2}=$ $\frac{2}{3}$. Konsep perkalian dan pembagian pada pecahan tidak jauh berbeda dengan konsep perkalian dan pembagian bilangan asli. Ketika terdapat $2 \times 3$ itu berarti ada 2 sebanyak 3, sehingga ketika $\frac{1}{2} \times \frac{1}{3}$ maka terdapat $\frac{1}{2}$ sebanyak $\frac{1}{3}$. Artinya didalam setiap bagian yang terpecah menjadi tiga terdapat bagian yang terpecah menjadi dua. Sedangkan konsep pembagian pada pecahan ketika terdapat 4:2 itu berarti ada 4 yang terbagi menjadi 2 sehingga ketika $\frac{1}{3}: \frac{1}{2}$ maka terdapat $\frac{1}{3}$ yang terbagi ke dalam $\frac{1}{2}$. Artinya, didalam setiap bagian yang terpecah menjadi tiga akan dibagi kedalam bagian yang terpecah menjadi dua (gambar 13).

\section{SIMPULAN}

Berpikir pseudo siswa pada konsep pecahan memang terjadi, pseudo pada konsep pecahan ini dialami oleh siswa kelas 4 SDN 1 Sumbersari kota Malang. Hasil temuan ini menunjukkan bahwa siswa mengalami berpikir pseudo pada konsep pecahan. Pseudo yang dialami siswa adalah berpikir pseudo conceptual, true-pseudo dan false-pseudo. Siswa tidak benar-benar memahami perlunya mengarsir saat menggambar pecahan, sehingga siswa dalam kondisi berpikir pseudo conceptual. Pada kondisi berpikir true-pseudo, siswa tidak memahami konsep menggambar pecahan berawal dari ukuran yang sama (kongruen) yang kemudian dipecah sebanyak penyebut pecahan. Pada kondisi berpikir false-pseudo, siswa kurang memahami maksud dari soal dan diperlukan refleksi akan konsep menggambar pecahan berawal dari ukuran yang sama (kongruen). Berpikir pseudo siswa dalam memahami konsep pecahan akan sangat diperlukan untuk mendapatkan perhatian. Guru perlu menyadari adanya siswa yang mengalami pseudo conceptual, true-pseudo, dan false-pseudo pada konsep pecahan yang telah diberikan. Hal ini akan menjadi sangat penting guna meningkatkan kualitas pemahaman siswa.

\section{DAFTAR RUJUKAN}

Alamsyah, A., \& Subanji. (2018). Proses Metakognisi Siswa dalam Menyelesaikan Masalah Open-Ended. Prosiding Silogisme, l(1), 15-23.

Behar-Horenstein, L. S., \& Niu, L. (2011). Teaching Critical Thinking Skills in Higher Education: A Review of the Literature. Journal of College Teaching \& Learning (TLC), 8(2), 25-42. https://doi.org/10.19030/tlc.v8i2.3554

Björklund, C., \& Pramling, N. (2014). Pattern Discernment and Pseudo-Conceptual Development in Early Childhood Mathematics Education. International Journal of Early Years Education, 22(1), 89-104. https://doi.org/10.1080/09669760.2013.809657

Clarke, D., Roche, A., \& Mitchell, A. (2011). One-to-One Student Interviews Provide Powerful Insights and Clear Focus for the Teaching of Fractions in the Middle Years. Fractions: Teaching for Understanding., 23-41.

DeWolf, M., Bassok, M., \& Holyoak, K. J. (2015). Conceptual Structure and the Procedural Affordances of Rational Numbers: Relational Reasoning with Fractions and Decimals. Journal of Experimental Psychology: General, 144(1), $127-150$. https://doi.org/10.1037/xge0000034

Fithriani, S. S., \& Hidayanto, E. (2018). Elementary School Teachers' Mathematical Connections in Solving Trigonometry Problem. Research in Social Sciences and Technology, 3(3), 32-41.

Hayati, I. N., Subanji, \& Qohar, A. (2016). Berpikir Pseudo Siswa Dalam Memecahkan Masalah PISA. Jurnal Pembelajaran Matematika, 3(1), 10-15.

Holisin, I. (2009). Melatih Penalaran Siswa Sekolah Dasar Dalam Memahami Konsep Bilangan Pecahan dan Menyelesaikan Masalah Penjumlahan dan Pengurangan Bilangan Pecahan. Didaktis, 8(3), 20-33.

Iuculano, T., \& Butterworth, B. (2011). Rapid Communication UnderstandingUnderstanding the Real Value of Fractions and Decimals. The Quarterly Journal of Experimental Psychology, 64(11), 2088-2098. https://doi.org/10.1080/17470218.2011.604785

Kurniawan, H., Nusantara, T., Subanji, S., Susiswo, S., Setiawan, I., Sutawidjaja, A., Muksar, M. (2016). Limited Intervention at Sub Concept of Fractions in the Object Conversion into Fractions. International Education Studies, 9(7), 145. https://doi.org/10.5539/ies.v9n7p145 
Kurniawan, H., Sutawidjaja, A., As'Ari, A. R., \& Muksar, M. (2018). Characteristic of Student's False Concessive Failure on Fractions Concept. Journal of Physics: Conference Series, 983(1). https://doi.org/10.1088/1742-6596/983/1/012173

Muhsetyo, G. (2014). Membandingkan Pecahan dengan Menggunakan Bahan Manipulatif Strip dan Menggunakan Benchmark.

Nur, F. (2009). Faktor-Faktor Penyebab Berpikir Pseudo dalam Menyelesaikan Soal-Soal Kekontinuan Fungsi Linear yang Melibatkan Nilai Mutlak berdasarkan Gaya Kognitif Mahasiswa. 69-91.

Permadi, W. E., \& Irawan, E. B. (2016). Memahamkan Konsep Pecahan pada Siswa Kelas IV SDN Sumberejo 03 Kabupaten Malang. Jurnal Pendidikan: Teori, Penelitian, dan Pengembangan, 1(9), 1735-1738.

Prayitno, L. L., Purwanto, P., Subanji, S., \& Susiswo, S. (2018). Identification Errors of Problem Posed by Prospective Teachers about Fraction Based Meaning Structure. International Journal of Insights for Mathematics Teaching, 1(1), 7684.

Puspendik. (2016). Trends in International Mathematics and Science Study, Result from TIMSS 2015. Pusat Penilaian Pendidikan Badan Penelitian dan Pengembangan, 1-2.

Rafiah, H., Saufi, M., Aulia, S., \& Riadi, A. (2018). Berpikir Pseudo Mahasiswa PGSD pada Operasi Bilangan Bulat. Math Didactic: Jurnal Pendidikan Matematika, 4(1), 11-20. https://doi.org/http://jurnal.stkipbjm.ac.id/index.php/math

Sa'dijah, C., Afriyani, D., Subanji, Muksar, M., \& Anwar, L. (2018). Assessing Students' Pseudo-Mathematical Translation Using Translation-Verification Model. AIP Conference Proceedings, 20144, 1-9. https://doi.org/10.1063/1.5054548

Sa'dijah, C., Rafiah, H., Gipayana, M., Qohar, A., \& Anwar, L. (2018). Asesmen Pemecahan Masalah Open-Ended untuk Mengukur Profil Berpikir Kreatif Matematis Siswa Berdasarkan Gender. Sekolah Dasar: Kajian Teori dan Praktik Pendidikan, 25(2), 147-159. https://doi.org/10.17977/um009v25i22016p147

Secolsky, C., Judd, T. P., Magaram, E., Levy, S. H., Kossar, B., \& Reese, G. (2016). Using Think-Aloud Protocols to Uncover Misconceptions and Improve Developmental Math Instruction : An Exploratory Study. Numeracy, 9(1), 1-16. https://doi.org/http://dx.doi.org/10.5038/1936-4660.9.1.6

Strother, S., Brendefur, J. L., Thiede, K., \& Appleton, S. (2016). Five Key Ideas to Teach Fractions and Decimals with Understanding. Advances in Social Sciences Research Journal, 3(2), 132-137. https://doi.org/10.14738/assrj.32.1832

Subanji. (2016a). Kerangka Dasar Berpikir Pseudo. Teori Berpikir Pseudo Penalaran Kovariasional, (October), 1-16. Retrieved from https://www.researchgate.net/publication/309288042_Bab_1_kerangka_dasar_berpikir_pseudo

Subanji, S. (2016b). Berpikir Pseudo Penalaran Kovariasi dalam Mengonstruksi Grafik Fungsi Kejadian Dinamik: Sebuah Analisis Berdasarkan Kerangka Kerja VL2P dan Implikasinya pada Pembelajaran Matematika. (February). https://doi.org/10.17977/jip.v13i1.57

Subanji, S., \& Nusantara, T. (2016). Thinking Process of Pseudo Construction in Mathematics Concepts. International Education Studies, 9(2), 17. https://doi.org/10.5539/ies.v9n2p17

Subanji., \& Maedi, S. A. (2015). The Pseudo-Covariational Reasoning Thought Processes in Constructing Graph Function of Reversible Event Dynamics Based on Assimilation and Accommodation Frameworks. Korean Society of Mathematical Education, 19(January), 61-79. https://doi.org/http://dx.doi.org/10.7468/jksmed.2015.19.1.61

Subanji, \& Nusantara, T. (2013). Karakterisasi Kesalahan Berpikir Siswa dalam Mengonstruksi Konsep Matematika. Jurnal Ilmu Pendidikan, 19(2), 208-217. https://doi.org/http://dx.doi.org/10.17977/jip.v19i2.4215

Van De Walle, J. (2010). Developing Fraction Concepts. Elementary and Middle School Mathematics: Teaching Developmentally, 286-308.

Van Steenbrugge, H., Remillard, J., Verschaffel, L., Valcke, M., \& Desoete, A. (2015). Teaching Fractions in Elementary School. The Elementary School Journal, 116(1), 49-75. https://doi.org/10.1086/683111

Vinner, S. (1997). The Pseudo-Conceptual and the Pseudo-Analytical Thought Processes in Mathematics Learning. Educational Studies in Mathematics, 34(November), 97-129. https://doi.org/10.1023/A

Wibawa, K. A. (2013). Defragmenting Berpikir Pseudo Siswa Dalam Memecahkan Masalah Limit. Seminar Nasional Exchange of Experiences Teacher Quality Improvement Program (TEQIP) 2013 “, 2(December 2015), 721-740.

Wibawa, K. A. (2016). Karakteristik Berpikir Pseudo Dalam Pembelajaran Matematika. Conference Problem Thinking Solving, (Conference Problem Thinking Solving View Paper Mathematics). https://doi.org/10.13140/RG.2.1.3907.3528 